\title{
PENGARUH OBJEKTIVITAS DAN INTEGRITAS AUDITOR INTERNAL TERHADAP KUALITAS AUDIT
}

(Studi Kasus Pada Inspektorat Daerah Se - Bandung Raya)

Oleh:

Indah Fitriani

(Dosen Program Studi Akuntansi FPEB Universitas Pendidikan Indonesia)

\author{
Yuga Luthfi Hidayat
}

(Alumni Program Studi Akuntansi FPEB Universitas Pendidikan Indonesia)

\begin{abstract}
This research is aim to know the influence of objectivity and integrity of internal auditors towards the audit quality partially and simultaneously, whether it significantly affects or not towards the audit quality on Inspektorat Daerah of Kota Bandung, Kota Cimahi, Kabupaten Bandung, and Kabupaten Bandung Barat. The method used for this research is the descriptive method, and the analysis used is the multiple linear regression analysis. The sampling technique for this research is saturated sampling. The result of the research with 5\% signification level shows that objectivity and integrity of internal auditors simultaneously influences the audit quality where the value $F(91,837)>$ the table $F(3,232)$, and objectivity of auditor partially influences significantly the audti quality where the value $T(4,914)>$ the table $T(2,021)$ as well as the integrity of auditor influences significantly the audit quality where the value $T(10,721)$ is bigger than the table $T(2,021)$.
\end{abstract}

Keywords: objectivity, integrity, audit quality

\section{Pendahuluan}

Pengguna laporan hasil pemeriksaan yang dilakukan oleh APIP menginginkan adanya aparat pengawasan yang bersih, berwibawa, tertib dan teratur dalam menjalankan tugas dan fungsinya sesuai ketentuan dan norma yang berlaku. Norma dan ketentuan yang berlaku bagi auditor intern pemerintah terdiri dari Kode Etik APIP dan Standar Audit APIP. Kode etik dimaksudkan untuk menjaga perilaku APIP dalam melaksanakan tugasnya, sedangkan Standar Audit dimaksudkan untuk menjaga mutu hasil audit yang dilaksanakan APIP. Dengan adanya aturan tersebut, masyarakat atau pengguna laporan dapat menilai sejauh mana auditor pemerintah telah bekerja sesuai dengan standar dan etika yang telah ditetapkan. (Sukriah, et.al, 2009)

Kode Etik APIP dalam Peraturan Menteri Negara Pendayagunaan Aparatur Negara (PERMENPAN) Nomor PER/04/M.PAN/03/2008, salah satu tujuannya adalah mencegah terjadinya tingkah laku yang tidak etis, agar terpenuhi prinsip-prinsip kerja yang akuntabel dan terlaksananya pengendalian audit 
sehingga terwujud auditor yang kredibel dengan kinerja yang optimal dalam pelaksanaan audit. Prinsip-prinsip perilaku yang berlaku bagi auditor antara lain integritas, objektivitas dan kompetensi. Integritas diperlukan agar auditor dapat bertindak jujur dan tegas dalam melaksanakan audit; objektivitas diperlukan agar auditor dapat bertindak adil tanpa dipengaruhi oleh tekanan atau permintaan pihak tertentu yang berkepentingan atas hasil audit; serta kompetensi auditor didukung oleh pengetahuan, dan kemampuan yang diperlukan untuk melaksanakan tugas. (Sukriah, et.al, 2009)

Standar Audit APIP sebagaimana diatur dalam PERMENPAN Nomor PER/05/M.PAN/03/2008, dipergunakan sebagai acuan bagi seluruh APIP dalam melaksanakan audit. Standar umum dalam standar audit tersebut antara lain mengatur tentang independensi APIP dan objektivitas auditor. Disebutkan dalam standar umum tersebut bahwa "dalam semua hal yang berkaitan dengan audit, APIP harus independen dan para auditornya harus objektif dalam pelaksanaan tugasnya". Hal ini mengandung arti bahwa independensi APIP serta objektivitas auditor diperlukan agar kualitas hasil pekerjaan APIP meningkat. (Sukriah, et.al, 2009)

Peran dan kinerja inspektorat daerah kini tengah menjadi sorotan masyarakat. Dalam Pikiran Rakyat Online (Senin, 26/03/2012) "Peran inspektorat daerah dalam mengawasi kinerja pemerintah daerah layak untuk diambil alih pemerintah pusat atau Kementerian Dalam Negeri (Kemendagri) RI. Sebab, selama ini Inspektorat Daerah dinilai tidak mampu memberikan transparansi dari hasil fungsi pengawasan yang dilakukan kepada kinerja Pemerintah Daerah." Dalam artikel tersebut juga disebutkan bahwa "Peran inspektorat daerah belum pernah terdengar fungsi jelasnya. Ada sejumlah asumsi yang mengatakan inspektorat daerah tidak berjalan sesuai perannya karena berada satu level dengan Satuan Kerja Perangkat Daerah (SKPD) dan dinas lain”. Bahkan, Pengamat dari Pusat Kajian Politik Ekonomi dan Pembangunan Kabupaten Bandung Barat Holid Nurjamil menduga, posisi inspektorat daerah yang mempunyai hierarki di bawah kepala daerah membuat fungsinya dianggap meragukan. Inspektorat daerah memiliki beban moral ketika berada di bawah kepala daerah. Ketika pengawasan ada di bawah kepala daerah, pengawasan kinerja pemerintah daerah tidak akan pernah dianggap objektif.

Dalam Rapat Paripurna Pembacaan Rekomendasi DPRD Kota Bandung terhadap Laporan Keterangan Pertanggungjawaban (LKPj) Wali Kota Bandung 2011 di Gedung DPRD Kota Bandung, Selasa (1/5), banyaknya temuan pada hasil pemeriksaan Badan Pemeriksa Keuangan (BPK) pada setiap SKPD termasuk Inspektorat sendiri, dianggap DPRD mencerminkan lemahnya pengawasan internal Inspektorat. "Untuk itu, Dewan meminta agar Wali Kota melakukan reformasi di tubuh Inspektorat Kota Bandung," tutur Erwan Setiawan. (Pikiran Rakyat Online, Selasa, 01/05/2012)

Hal tersebut mengindikasikan bahwa LKPj kota Bandung belum bisa dikatakan baik, bisa dilihat dari masih banyaknya temuan dari hasil pemeriksaan BPK. Hal ini berkaitan dengan perwujudan good governance yang harus didukung dengan pertanggungjawaban pemerintah. Jika akuntabilitas pemerintah baik, maka akan menghasilkan opini audit Wajar Tanpa Pengecualian. Namun pada 
kenyataannya, jarang sekali pemerintah daerah mendapatkan opini Wajar Tanpa Pengecualian. Untuk menghasilkan opini tersebut harus diimbangi dengan kualitas audit yang baik. Sedangkan untuk menciptakan kualitas audit yang baik harus didukung dengan objektivitas dan integritas auditor yang baik pula.

Fenomena lain yaitu dalam siaran pers BPK RI perwakilan Provinsi Jawa Barat mengenai penyampaian Laporan Hasil Pemeriksaan (LHP) BPK RI atas LKPD di Provinsi Jawa Barat. BPK RI memberikan opini Wajar Dengan Pengecualian (WDP) terhadap LKPD Kota Bandung, Kabupaten Bandung Barat, Kabupaten Bandung, dan Kota Cimahi untuk tahun anggaran 2011. Hal tersebut mengakibatkan kualitas audit yang dilakukan oleh auditor aparat Inspektorat menjadi perhatian masyarakat. Hal ini disebabkan dari temuan pemeriksaan audit tidak terdeteksi oleh aparat Inspektorat sebagai auditor internal. Akan tetapi ditemukan oleh Badan Pemeriksa Keuangan (BPK) sebagai auditor eksternal, ini menunjukkan bahwa kualitas audit aparat Inspektorat masih relatif kurang baik. (Rosnidah, et.al, 2011)

Tabel 1.1

Tindak Lanjut Hasil Audit Inspektorat Kabupaten/Kota

\begin{tabular}{||c||c|c|c||c|c|c||c|c|c||c|c||c||}
\hline \hline \multirow{2}{*}{ Inspektorat } & \multicolumn{3}{c||}{$\begin{array}{c}\text { Jumalah } \\
\text { Rekomendasi }\end{array}$} & \multicolumn{3}{c||}{$\begin{array}{c}\text { Belum Ditindak } \\
\text { Lanjut }\end{array}$} & \multicolumn{3}{c||}{ Tindak Lanjut Sedang } \\
Berjalan
\end{tabular}

Sumber: Data primer 2012, diolah

Berdasarkan tindak lanjut hasil audit yang dilakukan Inspektorat Kabupaten Bandung Barat ada beberapa temuan dan rekomendasi berkisar 7-15\% dari temuan tahun 2009-2011 yang belum selesai ditindak lanjut atau sedang berjalan. Begitupun Inspektorat Kota Cimahi, berkisar 35\% dari temuan tahun 2009 masih belum selesai ditindak lanjut. Bahkan di tahun 2011 ada temuan yang sama sekali belum ditindak lanjuti oleh Inspektorat. Hal tersebut menandakan bahwa kualitas audit Inspektorat masih kurang baik.

Selain itu berdasarkan temuan-temuan yang ditemukan oleh Inspektorat daerah Kota Cimahi dan Kabupaten Bandung Barat sering ditemukan temuan yang sama di tiga tahun terakhir. Seperti yang diungkapkan oleh Haryati yang menjabat sebagai P2UPD di Inspektorat kota Cimahi bahwa rata-rata temuan yang sering ditemukan yaitu dalam tiga hal: (1) Aset; (2) Pelayanan dan kedisiplinan; (3) Pencapaian kinerja.

Sementara di Kabupaten Bandung Barat juga terdapat temuan yang terus berulang dari tahun ke tahun. Moch. Lukmanul yang menjabat sebagai Kasubag Evaluasi dan Perencanaan mengatakan bahwa temuan yang sering berulang yaitu dalam hal: (1) Sistem Pengendalian Internal (SPI), yaitu aset dan persediaan, baik itu dalam hal penilaian maupun pencatatan; (2) Kepatuhan, yaitu kurangnya volume pekerjaan. 
Berbeda halnya dengan Inspektorat Kota Bandung, menurut Bagus Sukma yang menjabat sebagai auditor ahli pertama mengungkapkan bahwa Inspektorat Kota Bandung menghindari kejadian temuan yang berulang dari tahun ke tahun dengan cara langsung memberikan sanksi teguran yang dilaporkan kepada pimpinan SKPD atau kecamatan yang bersangkutan. Beliau mengatakan lebih lanjut temuan yang berulang dari tahun ke tahun tersebut mengindikasikan bahwa kinerja dan pembinaan Inspektorat kurang baik, dengan kata lain Inspektorat belum bisa dikatan memiliki kualitas audit yang baik.

Melihat fenomena-fenomena diatas, memunculkan pertanyaan apakah Inspektorat daerah memiliki kualitas audit yang baik dan apakah auditor memakai sikap objektivitas dan integritasnya dalam menjalankan tugas Negara. Terkait dengan konteks inilah, muncul pertanyaan seberapa tinggi tingkat objektivitas dan integritas auditor saat ini dan apakah objektivitas dan integritas auditor tersebut berpengaruh terhadap kualitas audit yang dihasilkan.

Objektivitas diduga berpengaruh terhadap kualitas hasil audit. Hasil penelitian Sukriah et.al (2009) menunjukkan bahwa objektivitas berpengaruh terhadap kualitas hasil pemeriksaan. Hai ini sejalan dengan penelitian yang dilakukan oleh Mabruri dan Winarna (2010) yang juga menunjukkan bahwa objektivitas berpengaruh secara signifikan terhadap kualitas hasil audit. Semakin tinggi tingkat objektivitas auditor, maka semakin baik kualitas hasil pemeriksaannya.

Faktor integritas auditor juga dapat berpengaruh terhadap kulitas hasil audit. Sunarto dalam Sukriah, et.al. (2009) menyatakan bahwa integritas dapat menerima kesalahan yang tidak disengaja dan perbedaan pendapat yang jujur, tetapi tidak dapat menerima kecurangan prinsip. Dengan integritas yang tinggi, maka auditor dapat meningkatkan kualitas hasil auditnya (Pusdiklatwas BPKP, 2005). Penelitian yang dilakukan Sukriah, et.al. (2009) menguji pengaruh integritas terhadap kualitas audit dan hasilnya tidak signifikan. Hal ini berbeda dengan penelitian yang dilakukan oleh Mabruri dan Winarna (2010) yang menunjukkan bahwa integritas berpengaruh secara signifikan terhadap kualitas audit.

Berdasarkan uraian latar belakang diatas, maka rumusan masalah dalam penelitian ini adalah apakah objektivitas auditor secara parsial berpengaruh terhadap kualitas audit, apakah integritas auditor secara parsial berpengaruh terhadap kualitas audit, dan apakah objektivitas dan integritas auditor secara simultan berpengaruh terhadap kualitas audit.

\section{Kajian Pustaka}

Untuk memenuhi tuntutan akuntabilitas publik dan good governance, diperlukan adanya pemeriksaan. Pemeriksaan (audit) ini harus dilakukan oleh pihak yang memiliki tingkat objektivitas dan integritas yang tinggi untuk memeriksa apakah hasil kinerja pemerintah telah sesuai dengan standar yang ditetapkan. Inspektorat daerah Kabupaten/Kota merupakan auditor internal pemerintah daerah yang melakukan fungsi audit pada pemerintah daerah.

Arens dan Loebbecke (2003) mengatakan bahwa objektivitas adalah suatu keyakinan, kualitas yang memberikan nilai bagi jasa atau pelayanan auditor. 
Pusdiklatwas BPKP (2005), menyatakan objektivitas sebagai bebasnya seseorang dari pengaruh pandangan subjektif pihak-pihak lain yang berkepentingan, sehingga dapat mengemukakan pendapat menurut apa adanya.

Sedangkan Sawyer, et.al (2006) menyatakan bahwa objektivitas berarti bahwa apa-apa yang dilaporkan adalah material sebuah permasalahan yang layak untuk mendapat perhatian seorang manajer yang sibuk. Suatu permasalahan hendaknya tidak dimasukkan ke dalam laporan sebagai embel-embel atau hanya untuk memperluas isi dari temuan audit.

Mabruri dan Winarna (2010) menyatakan semakin tinggi objektivitas auditor, maka semakin baik kualitas auditnya. Hubungan keuangan dengan klien dapat mempengaruhi objektivitas dan dapat mengakibatkan pihak ketiga berkesimpulan bahwa objektivitas auditor tidak dapat dipertahankan. Dengan adanya kepentingan keuangan, seorang auditor jelas berkepentingan dengan laporan hasil pemeriksaan yang diterbitkan. Standar umum dalam Standar Audit APIP menyatakan bahwa dengan prinsip objektivitas mensyaratkan agar auditor melaksanakan audit dengan jujur dan tidak mengkompromikan kualitas.

Sedangkan integritas merupakan kualitas yang melandasi kepercayaan publik dan merupakan patokan bagi anggota dalam menguji semua keputusannya. Integritas mengharuskan seorang auditor untuk bersikap jujur dan transparan, berani, bijaksana dan bertanggung jawab dalam melaksanakan audit. Keempat unsur itu diperlukan untuk membangun kepercayaan dan memberikan dasar bagi pengambilan keputusan yang andal (Pusdiklatwas BPKP, 2005).

Menurut Mulyadi (2002), integritas dapat menerima kesalahan yang tidak disengaja dan perbedaan pendapat yang jujur, tetapi tidak dapat menerima kecurangan atau peniadaan prinsip. Halim (2008) menyatakan bahwa "Faktor yang mempengaruhi kualitas audit adalah ketaatan auditor terhadap kode etik yang terefleksikan oleh sikap independensi, objektivitas dan integritas". Mabruri dan Winarna (2010) menyatakan bahwa kualitas audit dapat dicapai jika auditor memiliki integritas yang baik dan hasil penelitiannya menemukan bahwa integritas berpengaruh terhadap kualitas audit. Auditor sebagai ujung tombak pelaksanaan tugas audit harus senantiasa meningkatkan pengetahuan yang telah dimiliki agar penerapan pengetahuan dapat maksimal dalam praktiknya. Auditor sebagai ujung tombak pelaksanaan tugas audit harus senantiasa meningkatkan pengetahuan yang telah dimiliki agar penerapan pengetahuan dapat maksimal dalam praktiknya.

Kualitas audit menurut De Angelo yang dikutip Alim et.al. (2007) adalah sebagai probabilitas bahwa auditor akan menemukan dan melaporkan pelanggaran pada sistem akuntansi klien. Sedangkan Hardiningsih (2010) mengatakan bahwa kualitas audit merupakan segala kemungkinan (probability) dimana auditor pada saat mengaudit laporan keuangan klien dapat menemukan pelanggaran yang terjadi dalam sistem akuntansi klien dan melaporkannya dalam laporan keuangan auditan, dimana dalam melaksanakan tugasnya tersebut auditor berpedoman pada standar auditing dan kode etik akuntan publik yang relevan.

Beberapa penelitian tentang obektivitas, integritas, dan kualitas audit yang pernah dilakukan menyimpulkan temuan yang berbeda mengenai faktor yang mempengaruhi kualitas audit. Hasil penelitian Sukriah, et.al. (2009) menunjukkan 
bahwa objektivitas berpengaruh terhadap kualitas hasil pemeriksaan. Hal ini sejalan dengan penelitian yang dilakukan oleh Mabruri dan Winarna (2010) yang juga menunjukkan bahwa objektivitas berpengaruh secara signifikan terhadap kualitas hasil audit. Semakin tinggi tingkat objektivitas auditor, maka semakin baik kualitas hasil pemeriksaannya. Penelitian yang dilakukan Sukriah, et.al. (2009) menguji pengaruh integritas terhadap kualitas audit dan hasilnya tidak signifikan. Hal ini berbeda dengan penelitian yang dilakukan oleh Mabruri dan Winarna (2010) yang menunjukkan bahwa integritas berpengaruh secara signifikan terhadap kualitas audit.

\section{Metode Penelitian}

Berdasarkan tujuan yang ingin dicapai, maka penelitian ini menggunakan metode deskriptif. Sementara sumber data dalam penelitian ini diperoleh melalui penyebaran kuesioner. Kuesioner dalam penelitian ini disusun dengan nenggunakan Skala Likert dengan Skala Data Ordinal. Populasi yang digunakan dalam penelitian ini adalah seluruh auditor yang bekerja pada Inspektorat Daerah Kota Bandung, Kota Cimahi, Kabupaten Bandung, dan Kabupaten Bandung Barat. Pengambilan sampel dilakukan dengan teknik sampling jenuh. Adapun alat analisis yang digunakan adalah analisis regresi linier berganda.

\section{Hasil dan Pembahasan}

Data penelitian yang digunakan dalam penelitian ini merupakan data primer yang diperoleh dengan menggunakan daftar pertanyaan (kuesioner). Penyebaran kuesioner dilakukan kepada auditor pada Inspektorat Daerah Kota Bandung, Kota Cimahi, Kabupaten Bandung, dan Kabupaten Bandung Barat, untuk memperoleh data guna menganalisa sejauh mana pengaruh objektivitas auditor dan integritas auditor terhadap kualitas audit. Adapun realisasinya dapat dilihat pada tabel berikut:

\section{Tabel 1}

Tingkat Pengembalian Kuesioner

\begin{tabular}{|c|l|c|c|c|}
\hline No & \multicolumn{1}{|c|}{ Inspektorat Daerah } & $\begin{array}{c}\text { Jumlah } \\
\text { kuesioner } \\
\text { yang disebar }\end{array}$ & $\begin{array}{c}\text { Jumlah } \\
\text { kuesioner yang } \\
\text { dikembalikan }\end{array}$ & $\begin{array}{c}\text { Tingkat } \\
\text { pengembalian } \\
\text { kuesioner }\end{array}$ \\
\hline 1 & Kota Bandung & 15 & 14 & $93,33 \%$ \\
\hline 2 & Kota Cimahi & 5 & 5 & $100 \%$ \\
\hline 3 & Kabupaten Bandung Barat & 20 & 17 & $85 \%$ \\
\hline 4 & Kabupaten Bandung & 10 & 7 & $70 \%$ \\
\hline \multicolumn{2}{r|}{ Total } & 50 & 43 & $86 \%$ \\
\hline
\end{tabular}

\section{Tabel 2}

Demografi Responden

\begin{tabular}{|c|c|c|}
\hline Keterangan & Jumlah (orang) & Persentase \\
\hline Jenis kelamin: & 32 & \\
1. Pria & 11 & $74,42 \%$ \\
2. Wanita & & $25,58 \%$ \\
\hline
\end{tabular}

66 | Jurnal Riset Akuntansi dan Keuangan Vol.1 | No.1 | 2013 


\begin{tabular}{|c|c|c|}
\hline Usia: & & \\
1. <30 tahun & 3 & $6,98 \%$ \\
2. 30-40 tahun & 9 & $20,93 \%$ \\
3. 41-50 tahun & 26 & $60,47 \%$ \\
4. > 50 tahun & 5 & $11,63 \%$ \\
\hline Tingkat pendidikan: & 35 & \\
1. S1 & 8 & $18,60 \%$ \\
2. S2 & 3 & \\
\hline Masa kerja: & 8 & $18,98 \%$ \\
1. <5 tahun & 32 & $74,42 \%$ \\
2. 5-10 tahun & & \\
3. >10 tahun & & \\
\hline
\end{tabular}

\section{1) Hasil Pengujian Asumsi Normalitas}

Normalitas merupakan persyaratan yang sangat penting pada pengujian kebermaknaan (signifikansi) koefisien regresi, apabila model regresi tidak berdistribusi normal maka kesimpulan dari uji $\mathrm{F}$ dan uji t masih meragukan, karena statistik uji $\mathrm{F}$ dan uji t pada analisis regresi diturunkan dari distribusi normal. Pada penelitian ini digunakan uji satu sampel Kolmogorov-Smirnov untuk menguji normalitas model regresi dan berdasarkan hasil pengolahan data diperoleh hasil sebagai berikut.

Tabel 3

Hasil Pengujian Asumsi Normalitas

One-Sa mple Kolmogorov-Smirnov Test

\begin{tabular}{|ll|r|}
\hline & & $\begin{array}{c}\text { Unstandardiz } \\
\text { ed Residual }\end{array}$ \\
\hline Normal Parametersa,b & Mean & 43 \\
& Std. Deviation & .0000000 \\
Most Extreme & Absolute & .19136864 \\
Differences & Positive & .123 \\
& Negative & .123 \\
Kolmogorov-Smirnov Z & & -.073 \\
Asymp. Sig. (2-tailed) & & .805 \\
\hline
\end{tabular}

a. Test distribution is Normal.

b. Calculated from data.

Pada tabel 3 dapat dilihat nilai probabilitas (signifikansi) yang diperoleh dari uji Kolmogorov-Smirnov sebesar 0,536. Karena nilai probabilitas pada uji Kolmogorov-Smirnov masih lebih besar dari tingkat kekeliruan 5\% (0.05), maka disimpulkan bahwa model regresi berdistribusi normal.

\section{2) Pengujian Asumsi Heteroskedastisitas}

Heteroskedastisitas merupakan indikasi bahwa varian antar residual tidak homogen yang mengakibatkan nilai taksiran yang diperoleh tidak lagi efisien. Cara untuk mendeteksi ada atau tidaknya heteroskedastisitas adalah dengan melihat grafik scatter plot antara nilai prediksi variabel terikat (ZPRED) dengan nilai residualnya (SDRESID). Jika ada pola yang jelas dan titik-titik menyebar di 
atas dan dibawah angka 0 pada sumbu Y, maka terjadi heteroskedastisitas, sedangkan jika tidak membentuk pola atau acak maka tidak terjadi heteroskedastsitas. Hasil pengujian heteroskedastisitas pada penelitian ini dapat dilihat pada gambar berikut ini :

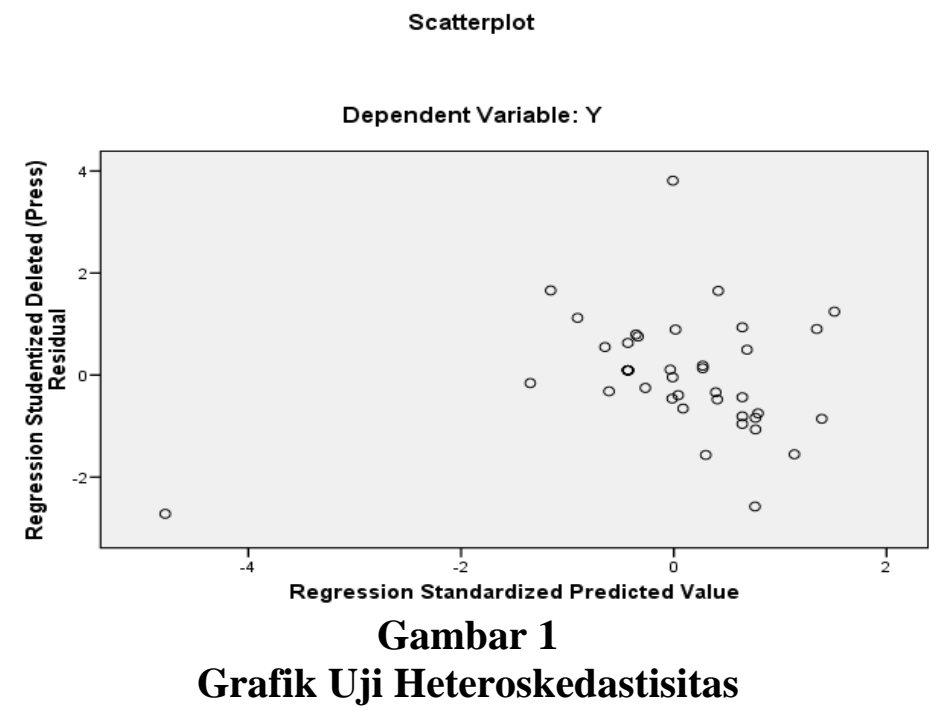

Dari grafik scatterplot, diperoleh titik-titik data tersebar secara acak diatas dan dibawah 0, sehingga disimpulkan tidak terjadi heteroskedastisitas pada persamaan regresi yang diperoleh.

\section{3) Pengujian Asumsi Multikolinieritas}

Multikolinieritas berarti adanya hubungan yang kuat di antara beberapa atau semua variabel independen pada model regresi. Jika terdapat Multikolinieritas maka koefisien regresi menjadi tidak tentu, tingkat kesalahannya menjadi sangat besar dan biasanya ditandai dengan nilai koefisien determinasi yang sangat besar tetapi pada pengujian parsial koefisien regresi, tidak ada ataupun kalau ada sangat sedikit sekali koefisien regresi yang signifikan. Pada penelitian ini digunakan nilai variance inflation factors (VIF) sebagai indikator ada tidaknya multikolinieritas diantara variabel independen.

\section{Tabel 4}

Hasil Pengujian Asumsi Multikolinieritas

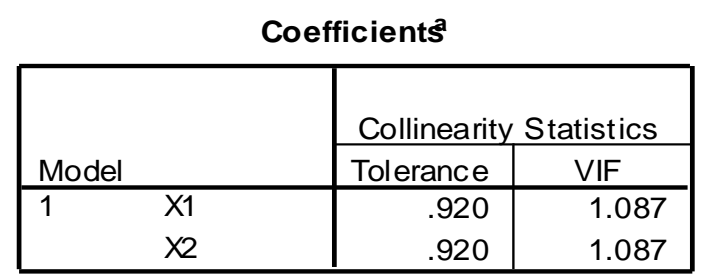

a. Dependent Variable: $Y$

Berdasarkan nilai VIF yang diperoleh seperti terlihat pada tabel 4 diatas menunjukkan bahwa tidak ada korelasi yang cukup kuat antara sesama variabel independen. Hal ini ditunjukkan oleh nilai VIF dari kedua variabel independen 
masih lebih kecil dari 10 sehingga dapat disimpulkan tidak terdapat gejala multikolinieritas diantara kedua variabel independen.

Model regresi digunakan untuk memprediksi dan menguji perubahan yang terjadi pada kualitas audit yang dapat diterangkan atau dijelaskan oleh perubahan kedua variabel independen (objektivitas auditor dan integritas auditor). Berdasarkan hasil pengolahan data objektivitas auditor dan integritas auditor terhadap kualitas audit diperoleh hasil regresi sebagai berikut.

\section{Tabel 5}

\section{Koefisien Regresi}

\section{Coefficients}

\begin{tabular}{|c|c|c|c|c|c|c|}
\hline \multirow{2}{*}{\multicolumn{2}{|c|}{ Model }} & \multicolumn{2}{|c|}{$\begin{array}{l}\text { Unstandardized } \\
\text { Coefficients }\end{array}$} & \multirow{2}{*}{$\begin{array}{c}\begin{array}{c}\text { Standardized } \\
\text { Coefficients }\end{array} \\
\text { Beta } \\
\end{array}$} & \multirow[b]{2}{*}{$t$} & \multirow[b]{2}{*}{ Sig. } \\
\hline & & $\mathrm{B}$ & Std. Error & & & \\
\hline & (Constant) & .281 & .231 & & 1.214 & .232 \\
\hline & $\mathrm{X} 1$ & .291 & .059 & .343 & 4.914 & .000 \\
\hline & $\times 2$ & .643 & .060 & .747 & 10.721 & .000 \\
\hline
\end{tabular}

a. Dependent Variable: $Y$

Melalui hasil pengolahan data seperti diuraikan pada tabel 5 maka dapat dibentuk model prediksi variabel objektivitas auditor dan integritas auditor terhadap total kualitas audit sebagai berikut.

$$
Y=0,281+0,291 X_{1}+0,643 X_{2}
$$

Tabel 6

Anova Untuk Pengujian Koefisien Regresi secara Bersama-sama ANOVA

\begin{tabular}{|c|c|c|c|c|c|c|}
\hline \multicolumn{2}{|c|}{ Model } & $\begin{array}{l}\text { Sum of } \\
\text { Squares }\end{array}$ & df & Mean Square & $\mathrm{F}$ & Sig. \\
\hline \multirow[t]{3}{*}{1} & Regression & 7.063 & 2 & 3.531 & 91.837 & $.000^{\mathrm{a}}$ \\
\hline & Residual & 1.538 & 40 & .038 & & \\
\hline & Total & 8.601 & 42 & & & \\
\hline
\end{tabular}

a. Predictors: (Constant), X2, X1

b. Dependent Variable: $Y$

Berdasarkan tabel anova di atas dapat dilihat bahwa nilai F hitung $(91,837)$ $>\mathrm{F}$ tabel $(3,232)$. Hasil penelitian ini dengan tingkat signifikansi 5\% menunjukan bahwa objektivitas auditor dan integritas auditor secara bersama-sama (simultan) berpengaruh signifikan terhadap kualitas audit pada Inspektorat Daerah Kota Bandung, Kota Cimahi, Kabupaten Bandung, dan Kabupaten Bandung Barat.

Tabel 7

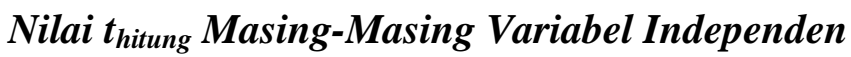

\begin{tabular}{|l|l|l|l|}
\hline Model & T & Sig & Keterangan \\
\hline
\end{tabular}




\begin{tabular}{|ll|r|r|l|}
\hline 1 & (Constant) & 1.214 & .232 & \\
& X1 & 4.914 & .000 & Signifikan \\
& X2 & 10.721 & .000 & Signifikan \\
\hline
\end{tabular}

Nilai tabel yang digunakan sebagai nilai kritis pada uji parsial (uji t) sebesar 2,021 yang diperoleh dari tabel t pada $\alpha=0.05$ dan derajat bebas 40 untuk pengujian dua pihak. Dari tabel 7 di atas dapat dilihat bahwa secara parsial objektivitas auditor berpengaruh yang signifikan terhadap kualitas bukti audit yang dikumpulkan dimana $\mathrm{T}$ hitung $(4,914)>(2,021)$, demikian juga dengan integritas auditor berpengaruh secara signifikan terhadap kualitas bukti audit yang dikumpulkan dimana $\mathrm{T}$ hitung $(10,721)>\mathrm{T}$ tabel $(2,021)$.

\section{Tabel 8 \\ Koefisien Determinasi}

\begin{tabular}{|l|r|r|r|r|}
\multicolumn{7}{c|}{ Model Summary } \\
\hline Model & $\mathrm{R}$ & R Square & $\begin{array}{c}\text { Adjusted } \\
\text { R Square }\end{array}$ & $\begin{array}{r}\text { Std. Error of } \\
\text { the Estimate }\end{array}$ \\
\hline 1 & $.906^{\mathrm{a}}$ & .821 & .812 & .19609 \\
\hline
\end{tabular}

a. Predictors: (Constant), X2, X1

b. Dependent Variable: $Y$

Berdasarkan tabel 8 di atas dapat diketahui bahwa hasil perhitungan koefisien determinasi secara bersama-sama kedua variabel independen (objektivitas auditor dan integritas auditor) memberikan kontribusi atau pengaruh sebesar 82,1\% terhadap kualitas audit pada Inspektorat Daerah Kota Bandung, Kota Cimahi, Kabupaten Bandung, dan Kabupaten Bandung Barat. Sisanya pengaruh faktor-faktor lain yang tidak diteliti adalah sebesar 17,9\%, yaitu merupakan pengaruh faktor lain diluar kedua variabel independen yang diteliti.

\section{Simpulan}

1. Objektivitas sebagian besar auditor pada Inspektorat Daerah Kota Bandung, Kota Cimahi, Kabupaten Bandung, dan Kabupaten Bandung Barat sudah tinggi. Hasil pengujian menunjukkan bahwa objektivitas auditor berpengaruh signifikan terhadap kualitas audit pada Inspektorat Daerah Kota Bandung, Kota Cimahi, Kabupaten Bandung, dan Kabupaten Bandung Barat. Objektivitas auditor yang tinggi akan meningkatkan kualitas audit pada Inspektorat Daerah Kota Bandung, Kota Cimahi, Kabupaten Bandung, dan Kabupaten Bandung Barat.

2. Integritas sebagian besar auditor pada Inspektorat Daerah Kota Bandung, Kota Cimahi, Kabupaten Bandung, dan Kabupaten Bandung Barat sudah sangat tinggi. Hasil pengujian menunjukkan bahwa integritas auditor berpengaruh signifikan terhadap kualitas audit pada Inspektorat Daerah Kota Bandung, Kota Cimahi, Kabupaten Bandung, dan Kabupaten Bandung Barat. Semakin tinggi integritas yang dimiliki auditor akan meningkatkan kualitas audit pada Inspektorat Daerah Kota Bandung, Kota Cimahi, Kabupaten Bandung, dan Kabupaten Bandung Barat. 
3. Objektivitas auditor dan integritas auditor secara bersama-sama berpengaruh signifikan terhadap kualitas audit pada Inspektorat Daerah Kota Bandung, Kota Cimahi, Kabupaten Bandung, dan Kabupaten Bandung Barat. Objektivitas auditor dan integritas auditor secara bersama-sama memberikan pengaruh sebesar $82,1 \%$ terhadap kualitas audit pada Inspektorat Daerah Kota Bandung, Kota Cimahi, Kabupaten Bandung, dan Kabupaten Bandung Barat. Diantara kedua variabel independen, integritas auditor memberikan pengaruh yang lebih besar terhadap kualitas audit.

\section{Saran}

1. Sebagian besar objektivitas auditor pada Inspektorat Daerah Kota Bandung, Kota Cimahi, Kabupaten Bandung, dan Kabupaten Bandung Barat sudah tinggi, hal ni tentu harus bisa dipertahankan. Namun bila dilihat berdasarkan butir pernyataan, terlihat bahwa rata-rata skor tanggapan responden sebagian besar termasuk dalam kategori sangat tinggi, dan ada juga yang termasuk dalam kategori cukup. Yang termasuk kategori cukup yaitu mengenai penolakan penugasan audit dengan pihak yang memiliki hubungan kerjasama, paling banyak responden sering menolak penugasan audit dengan pihak yang memiliki hubungan kerjasama. Namun banyak juga responden yang hanya kadang-kadang bahkan ada yang pernah dan tidak pernah menolak penugasan audit dengan pihak yang memiliki hubungan kerjasama. Oleh karena itu diharapkan auditor pada Inspektorat Daerah tidak berpartisipasi dalam kegiatan atau hubungan-hubungan yang mungkin mengganggu atau dianggap mengganggu penilaian yang tidak memihak atau yang mungkin menyebabkan terjadinya benturan kepentingan agar objektivitasnya tetap terjaga sehingga akan menghasilkan kualitas audit yang baik.

2. Sebagian besar integritas auditor pada Inspektorat Daerah Kota Bandung, Kota Cimahi, Kabupaten Bandung, dan Kabupaten Bandung Barat sudah sangat tinggi. Demikian juga bila dilihat berdasarkan butir pernyataan, terlihat bahwa rata-rata skor tanggapan responden terhadap sebagian besar butir pernyataan termasuk dalam kategori sangat tinggi. Agar dapat lebih meningkatkan kualitas audit maka disaranakan bagi auditor Inspektorat Daerah untuk mengikuti pendidikan dan pelatihan, ujian sertifikasi maupun jabatan fungsional.

3. Kualitas audit Inspektorat Daerah Kota Bandung, Kota Cimahi, Kabupaten Bandung, dan Kabupaten Bandung Barat secara umum sudah sangat baik. Demikian juga bila dilihat berdasarkan butir pernyataan, terlihat bahwa ratarata skor tanggapan responden terhadap sebagian besar butir pernyataan termasuk dalam kategori sangat baik. Namun jika dilihat dari item pernyataan ada beberapa pada indikator standar tindak lanjut yang termasuk dalam kategori cukup. Melihat fenomena yang terjadi mengenai tindak lanjut hasil audit yang menandakan bahwa kualitas audit inspektorat masih kurang baik, hal tersebut tentu harus menjadi perhatian baik bagi inspektorat maupun auditor agar bisa meningkatkan kualitas audit dengan cara memperbaiki tindak lanjut hasil audit yang dilakukan. 
4. Penelitian ini hanya menggunakan objektivitas auditor dan integritas auditor sebagai variabel independen yang mempengaruhi kualitas audit. Oleh karena itu disarankan pada penelitian selanjutnya untuk menggunakan variabel independen lainnya, seperti tanggung jawab, independensi, kecermatan, lingkup dan sifat jasa, kepatuhan terhadap standar umum dan prinsip akuntansi, dan lain sebagainya yang dapat berpengaruh terhadap kualitas audit. Disaranakan pula agar penelitian selanjutnya dilaksanakan pada perusahaan daerah dengan populasi sasaran yaitu auditor internal pada Perusahaan Daerah, agar dapat terlihat perbandingan antara kualitas audit yang dihasilkan oleh Inspektorat Daerah dengan Perusahaan Daerah.

\section{Daftar Pustaka}

Alim, M.N., et.al. (2007). "Pengaruh Kompetensi dan Independensi terhadap Kualitas Audit dengan Etika Auditor sebagai Variabel Moderasi”. Simposium Nasional Akuntansi X. Makassar

Arens, Alvin. A dan Loebbecke James .K. (2003). Auditing (Pendekatan Terpadu). Buku I. Edisi Indonesia. Jakarta: Salemba Empat.

Halim, Abdul. (2008). Auditing (dasar-dasar Audit Laporan Keuangan). UUP STIM.

Hardiningsih, Pancawati. (2010). "Pengaruh Independensi, Corporate Governance, dan Kualitas Audit Terhadap Integritas Laporan Keuangan". Kajian Akuntansi Vol. 2 No. 1

Mabruri, Havidz dan Jaka Winarna. (2010). "Analisis Faktor-Faktor Yang Mempengaruhi Kualitas Hasil Audit di Lingkungan Pemerintah Daerah". Simposium Nasional Akuntansi XIII. Purwokerto.

Mulyadi. (2002). Auditing. Edisi 6. Jakarta: Salemba Empat.

Pusdiklatwas BPKP. (2005). Kode Etik dan Standar Audit. Edisi Keempat.

Rosnidah, Ida., et.al. (2011). “Analisis Dampak Motivasi Dan Profesionalisme Terhadap Kualitas Audit Aparat Inspektorat Dalam Pengawasan Keuangan Daerah". Pekbis Jurnal, Vol.3, No.2.

Sawyer, Lawrence B., et.al. (2006). Audit Internal Sawyer Edisi 5 Buku 2. Jakarta: Salemba Empat.

Sukriah, Ika., et.al. (2009). "Pengaruh Pengalaman Kerja, Independensi, Obyektifitas, Integritas dan Kompetensi Terhadap Kualitas Hasil Pemeriksaan". Simposium Nasional Akuntansi XII. Palembang. (2012, 1 Mei). DPRD Kota Bandung Soroti Kinerja Enam SKPD. Pikiran Rakyat [Online]. Tersedia: http://www.pikiran-rakyat.com [3 Mei 2012] (2012, 26 Maret). Inspektorat Daerah Lemah, Pusat Harus Ambil Alih. Pikiran Rakyat [Online]. Tersedia: http://www.pikiran-rakyat.com. [30 April 2012] 